\title{
Zebra mussel (Dreissena polymorpha) affects the feeding ecology of early stage striped bass (Morone saxatilis) in the Hudson River estuary
}

\author{
Michael G. Smircich • David L. Strayer • Eric T. Schultz
}

Received: 5 February 2016 / Accepted: 26 October 2016 / Published online: 17 December 2016

(C) The Author(s) 2016. This article is published with open access at Springerlink.com

\begin{abstract}
Variability in the feeding ecology of young fishes over short and long time scales in estuaries is likely to affect population dynamics. We studied 14 years of early stage Striped Bass feeding ecology in the Hudson River Estuary over a 25-year time span, including years in which invasive zebra mussels markedly altered energy flow within the estuary. We predicted that feeding success would be low and that diet composition would be altered during years of high zebra mussel impact, particularly in upriver locations where mussels occur. Feeding success in the short term was indicated by volume of gut contents and in the long term by dry mass at length, i.e. condition; these measures were positively intercorrelated and varied significantly year to year. We tested for associations between condition and multiple biotic and abiotic environmental variables. There was a strong negative effect of zebra mussel grazing rate on condition in upriver locations and a weak positive effect in downriver locations. In upriver locations, condition was 33\% higher when local salinity was high and zebra mussel grazing rates were low, whereas in downriver locations, condition was $35 \%$ higher when zebra mussel grazing rates and copepod abundance were high and local dissolved oxygen was low. Copepods,
\end{abstract}

M. G. Smircich • E. T. Schultz $(\bowtie)$

Department of Ecology and Evolutionary Biology, University of Connecticut, 75 North Eagleville Road, Storrs, CT 06269-3043, USA

e-mail: eric.schultz@uconn.edu

D. L. Strayer

Cary Institute of Ecosystem Studies, 2801 Sharon Turnpike;

P.O. Box AB, Millbrook, NY 12545, USA amphipods, mysids, and Leptodora constituted the highest prey-specific index of relative importance throughout the estuary. There was no evident effect of the zebra mussel invasion on diet composition. This long-term study corroborates the inferences of earlier studies that zebra mussels reduced early-stage striped bass growth rate.

Keywords ANOSIM · Condition · Invasive species · Trophic ecology

\section{Introduction}

Estuaries are dynamic, variable systems that serve as a critical nursery habitat for many coastal fishes (MacLusky and Elliott 2004), offering favorable feeding conditions (Blaber and Blaber 1980; Friedland et al. 1996). Food abundance as well as abiotic conditions can fluctuate greatly over space and time. Given this variability, longterm studies of estuarine ecology can be particularly informative. Long-term data are critical for quantifying ecological response to environmental changes, understanding expression of key ecological trends, providing core data for parameterizing models, influencing management of species or ecosystems, and acting as the basis of collaborative studies (Lindenmayer et al. 2012). The goal of this study is to document the long-term feeding ecology of early stage estuary-dependent Striped Bass (Morone saxatilis [Walbaum, 1792]).

Studying fish feeding ecology addresses fundamental questions including what prey was consumed and when it was consumed. Diet analyses also provide insight 
towards broader subjects such as population dynamics (Braga et al. 2012), habitat use (Feitosa and Ferreira 2015), evolution (Collar et al. 2009), energy flow between ecosystems (Baxter et al. 2005), and conservation (Alcaraz et al. 2015; Donadelli et al. 2015). Characterizing the diet of early-stage fishes is particularly important because this is when fish grow most rapidly and undergo ontogenetic shifts that are critical to survival. The early life stages of anadromous fish within estuaries are typically the only times these fish can easily be captured until they arrive back into freshwater as spawning adults. Generally the feeding of young fishes has not been studied as much as that of adults due to additional difficulties associated with collection and analysis of specimens (Gerking 1994), and patterns in feeding ecologies of estuarine larvae relative to other habitats remain poorly characterized (Llopiz 2013).

The Hudson River Estuary is a body of water that hosts many early stage fish species, including nearly a dozen diadromous fishes (Waldman 2006). The estuary is a complex, well-studied system in which several longterm environmental data collection programs have been in place for multiple decades (Levinton and Waldman 2006). The estuary has historically undergone major ecological changes, including the recent invasion of zebra mussels (Dreissena polymorpha [Pallas, 1771]). Zebra mussels first appeared in the Hudson River in 1991, and have been abundant throughout the freshwater portion of the estuary since then (Strayer et al. 2011). The mussels sharply reduced phytoplankton biomass and markedly altered estuarine energy flow (Pace et al. 1998; Pace et al. 2010; Strayer et al. 2014b). Within the first two years of mussel establishment, total phytoplankton biomass declined 85\% (Caraco et al. 1997), zooplankton biomass declined by more than $70 \%$ (Pace et al. 1998), and zoobenthos biomass declined by $40 \%$ (Strayer and Smith 2001). Strayer et al. (2004) found that growth and abundance decreased, and distribution changed, of early stage pelagic fishes in the estuary following the invasion. Subsequently, many musselinduced ecological impacts within the river diminished towards pre-invasion levels due to a decrease in average mussel size (Strayer et al. 2014a). The effects of these changes on feeding success and diet composition of larval fish in the Hudson River has not yet been studied, excepting one finding that larval shad consume zebra mussel veligers (Nack et al. 2015).

Long-term analysis of early stage fish feeding ecology in the estuary is facilitated by extensive monitoring. In particular, The Hudson River Utilities Longitudinal River Survey began in 1973 to estimate the impact of five electric generating stations on Striped Bass, White Perch (Morone americana [Gmelin, 1789]), and Atlantic Tomcod (Microgadus tomcod [Walbaum, 1792]). Annual reports of this survey ("year-class reports" e.g., ASA Analysis and Communication 2016) provide data on distribution and abundance of early life stages of selected fish species throughout the estuary, with associated physicochemical data. Furthermore, ichthyoplankton samples from this survey have been archived and made available for research through Normandeau Associates and the New York State Museum. With well-defined objectives and sound statistical design, such long-term monitoring program offer important opportunities for scientific research on the effects of environmental change (Lindenmayer and Likens 2009).

Striped Bass is a species of particular interest in the Hudson River Estuary ichthyoplankton. Striped Bass once comprised a commercial fishery in the Hudson River until it was closed in the mid-1970's because of PCB contamination (Waldman 2006). Today they are perhaps the most popular sport fish in the river. Striped Bass are anadromous, spending most of their adult life in marine waters and entering the estuary in the spring to spawn in the fresh waters of the middle and upper estuary (O'Connor et al. 2012). They are typically described as feeding opportunists (Hurst and Conover 2001), but at least one study documented selective feeding (Howe et al. 2008). Prior studies of larval Striped Bass diet showed that they consumed mainly copepods, Bosmina, and amphipods (Brett and Groves 1979; Hurst and Conover 2001; Jordan et al. 2003; Limburg et al. 1997; Morgan et al. 1981). Based on analysis of seasonal change in size distribution of juvenile striped bass, Strayer et al. (2004) concluded that the zebra mussel invasion had reduced the feeding success and growth rate of this species in the estuary. Data on how feeding success and diet were affected would be useful and have not been provided in other studies of early stage Striped Bass or other species.

The purpose of this study is to characterize early-stage Striped Bass diet composition and feeding success over a 25-year period in the Hudson River Estuary. We focus on three main goals: 1) to describe diet composition and evaluate feeding success over a multi-decade time span; 2) to test for effects of zebra mussels on the feeding ecology of Striped Bass; and, 3) determine what ecological factors most influence Striped Bass long-term feeding 
success. We predicted reduced feeding success and a change in diet composition during years of mussel impact, particularly in freshwater areas of the estuary inhabited by the mussels. Given the variable nature of estuaries, we expected that changes in additional environmental factors could also affect feeding success.

\section{Methods}

Samples were collected and archived as part of the Hudson River Utilities Longitudinal River Survey. The ichthyoplankton survey samples the entire length of the estuary with a $1.0-\mathrm{m}^{2}$ Tucker trawl in a stratified random design; sampling is weekly from early April through June and then biweekly until September. During the season that samples we analyzed are collected, all samples are taken at night (20:00 to 05:00). Larval fish samples were preserved in $10 \%$ formalin. No consistent effect of formalin preservation on fish length and mass is apparent across multiple studies (Johnston and Mathias 1993; Parker 1963; Schultz et al. 2005; Shields and Carlson 1996; Yeh and Hodson 1975). We assumed shrinkage to be uniform throughout our samples and did not correct for it in our analyses. The years analyzed for this study included: 1988, 1991-93, 1997, 1999, 2003, 2005-07, 2009-12. Years were selected based on sample availability within our study time frame. For analysis of zebra mussel effects, we grouped these years into three periods (Pace et al. 2010): “preinvasion" (1988-1992), "invasion impact" (1993-2004), and "recovery" (2005-present).

Undamaged early-stage Striped Bass were selected for analysis based on developmental stage, time of year, and location. Sixty fish per year were selected from samples containing larval and juvenile Striped Bass, taken during the growing season (early June until midSeptember). In total, 840 specimens were used for this study. When possible, 30 fish each year were analyzed from each of two estuary locations (Table 1), upriver (river $\mathrm{km} \geq 96$ ) and downriver (river $\mathrm{km}<96$ ). This partitioning of the river corresponds roughly to the average seasonal position of the salt front. Zebra mussels are generally restricted to upriver freshwater areas.

Each selected specimen was measured for length, dissected for gut contents, and then dried. All specimens were photographed and digitally measured to the nearest $0.01 \mathrm{~mm}$ using SigmaScan ${ }^{\circledR}$ Pro 5.0 (Systat Software Inc., San Jose, CA). Specimen length (Table 1) ranged from $6 \mathrm{~mm}$ to $60 \mathrm{~mm}$ (mean $24 \mathrm{~mm}$, standard deviation $11 \mathrm{~mm}$ ). This size range encompasses larval and juvenile stages, which can be differentiated at about $30 \mathrm{~mm}$ (Hardy 1978). Specimens were placed into a drying oven for $48 \mathrm{~h}$ at $60{ }^{\circ} \mathrm{C}$ for determination of dry mass. We preserved gut contents in $70 \%$ ethanol (Hyslop 1980; Jude 1973). We estimated volume of gut contents after they had settled for $24 \mathrm{~h}$ in $1.5 \mathrm{ml}$ conical vials.

Table 1 Summary of sample sizes per bass life stage ( $\mathrm{L}=$ larvae, $\mathrm{J}=$ juvenile), mean length per year ( $\mathrm{mm})$, and standard deviation of length (SD) in upriver and downriver locations. Fish less than $30 \mathrm{~mm}$ were considered to be larvae

\begin{tabular}{|c|c|c|c|c|c|c|}
\hline \multirow[b]{2}{*}{ Year } & \multicolumn{3}{|l|}{ Upriver } & \multicolumn{3}{|c|}{ Downriver } \\
\hline & $\mathrm{L} / \mathrm{J}$ & Mean length & (SD) & $\mathrm{L} / \mathrm{J}$ & Mean length & (SD) \\
\hline 1988 & $11 / 28$ & 22.1 & $(5.4)$ & $10 / 20$ & 36.0 & (11.4) \\
\hline 1991 & $20 / 44$ & 20.8 & (7.4) & $5 / 5$ & 40.0 & (20.4) \\
\hline 1992 & $17 / 30$ & 14.2 & $(2.6)$ & $17 / 13$ & 28.2 & $(17.2)$ \\
\hline 1993 & $13 / 23$ & 21.7 & (15.4) & $24 / 6$ & 23.6 & (13.2) \\
\hline 1997 & $7 / 17$ & 17.7 & $(8.1)$ & $36 / 5$ & 19.4 & $(7.0)$ \\
\hline 1999 & $12 / 18$ & 19.8 & (4.3) & $32 / 9$ & 25.2 & (11.8) \\
\hline 2003 & $16 / 23$ & 23.9 & $(8.7)$ & $11 / 19$ & 40.1 & (15.7) \\
\hline 2005 & $7 / 30$ & 19.1 & (3.4) & $26 / 4$ & 21.8 & $(6.8)$ \\
\hline 2006 & $9 / 29$ & 20.9 & (3.9) & $17 / 13$ & 29.1 & $(9.0)$ \\
\hline 2007 & $10 / 19$ & 16.7 & $(5.5)$ & $26 / 15$ & 26.2 & $(9.7)$ \\
\hline 2009 & $6 / 30$ & 18.2 & $(2.4)$ & $28 / 2$ & 19.7 & $(6.2)$ \\
\hline 2010 & $4 / 29$ & 20.9 & $(4.4)$ & $23 / 7$ & 26.6 & $(4.0)$ \\
\hline 2011 & $9 / 18$ & 21.4 & $(8.1)$ & $23 / 16$ & 26.2 & $(8.7)$ \\
\hline 2012 & $5 / 22$ & 22.3 & $(4.4)$ & $33 / 4$ & 25.8 & $(4.9)$ \\
\hline
\end{tabular}


The height of the settled contents was measured to the nearest $0.01 \mathrm{~mm}$ and converted to volume in $\mu \mathrm{l}$ using an empirical calibration formula.

We tested for temporal and spatial effects (year and zebra mussel period, upriver and downriver locations) on two measures of feeding success. Volume of gut contents represented a measure of short-term feeding success and condition (dry mass at length as suggested by Jakob et al. 1996) represented a longer-term measure of feeding success. Only specimens that had gut contents, comprising about $75 \%$ of specimens, were included in analysis of short-term feeding success. Analysis of temporal change in both measures of feeding success ( $\log _{10}$-transformed) was conducted in analysis of covariance (ANCOVA) in which predictors were $\log _{10}$ (length), zebra mussel period (pre-invasion, invasion impact, recovery), year nested within period, and the interaction between length and year. Year nested within period was treated as a random effect, the mean square of which was the denominator in F-tests of the effect of period. We conducted separate analyses by location (upriver or downriver) because of significant interactions with other main effects. We also conducted mixed linear modeling by location, in which sample tow was encoded as a random effect to account for the nonindependence of specimens collected in the same ichthyoplankton sample. The ANCOVA and mixed linear model analyses were designed to test the prediction that feeding success was reduced during the impact period relative to the pre-invasion and recovery periods. Because we expected the reduction in feeding success to be most pronounced in the upriver location, we tested for an effect of mussel period, via one-way analysis of variance, on the difference in each year between the upriver and downriver predicted values of each measure of feeding success, adjusted to a common mean size. Analyses were run in SAS for Windows 9.4 (SAS Institute, Inc., Cary NC: PROC GLM, PROC CORR, PROC MIXED, and PROC ANOVA).

We tested seven abiotic and biotic environmental factors (Table 2) via mixed linear modeling to identify those factors that were most associated with longer-term feeding success, as measured by dry mass-at-length. We conducted separate analyses by location (upriver and downriver). Abiotic data (salinity, dissolved oxygen, temperature) were collected at the same times and locations as ichthyoplankton samples. In contrast, biotic data were obtained from monitoring programs of the Cary Institute of Ecosystem Studies and were represented in
Table 2 Summary statistics of environmental variables used in mixed modeling. Two values (upriver/downriver) are presented for abiotic variables that were measured in conjunction with sampling for early-stage Striped Bass, whereas one value is presented for biotic variables that were measured at a fixed single site. The 5 th and 95th percentiles were used to quantify the effect of selected variables on condition

\begin{tabular}{llll}
\hline Environmental variable & Mean & $\begin{array}{l}\text { 5th } \\
\text { Percentile }\end{array}$ & $\begin{array}{l}\text { 95th } \\
\text { Percentile }\end{array}$ \\
\hline Amphipods $^{\mathrm{a}}\left(\mathrm{no.}^{-2}\right)$ & 1100 & 380 & 3300 \\
${\text { Chlorophyll } \mathrm{a}^{\mathrm{a}}\left(\mu \mathrm{g} \mathrm{l}^{-1}\right)}$ & 9.8 & 4.1 & 29 \\
Copepods $^{\mathrm{a}}\left(\mathrm{no.}^{-1}\right)$ & 7 & 3.4 & 17 \\
$\mathrm{DO}^{\mathrm{b}}\left(\mathrm{mg} \mathrm{l} \mathrm{l}^{-1}\right)$ & $7.5 / 6.6$ & $6.2 / 5.6$ & $8.9 / 7.9$ \\
Salinity $^{\mathrm{b}}(\mathrm{ppt})$ & $0.21 / 3.3$ & $0.1 / 0.1$ & $0.9 / 7.8$ \\
Temperature $^{\mathrm{b}}$ & $24 / 25$ & $21 / 22$ & $26 / 28$ \\
ZM filtration rate $^{\mathrm{a}}\left(\mathrm{m}^{3} \mathrm{~m}^{-2} \mathrm{~d}^{-1}\right)$ & 3.4 & 0.063 & 8.3 \\
\hline
\end{tabular}

${ }^{\text {a }}$ Cary Institute of Ecosystem Studies data; data are annual averages collected at the Kingston long-term monitoring station

${ }^{\mathrm{b}}$ Hudson River Utilities data; data were collected in conjunction with ichthyoplankton tows throughout the estuary; squared values also used in modeling to test for a quadratic response

our analyses as annual averages because they were not taken on the same time scale or in same locations as ichthyoplankton samples. Biotic data included measures of water column production (chlorophyll a, copepod abundance), benthic production (amphipod abundance) and zebra mussel impact (zebra mussel filtration rate; see Strayer et al. 1996 for details about how this is estimated). In pre-invasion years, zebra mussel filtration rate was zero or negligibly small (Strayer et al. 1996). In predictive regressions, we included quadratic terms for abiotic variables (centered to a mean of 0 before squaring to reduce collinearity between first-order and second-order terms), because we had no prior expectations that the response to abiotic predictors would be linear. In all models, the response variable was $\log _{10}$ (dry mass), and $\log _{10}$ (length) was included as a covariate. Sample tow was encoded as a random effect. The best models of 1023 candidate models were selected by information-theoretic criteria, i.e. AIC and related statistics (Akaike 1974; Burnham and Anderson 2002). Models were ranked as best to worst in order of increasing AIC; each model was compared to the best in terms of their difference in AIC, and the relative likelihood of each model was estimated as Akaike weight. We evaluated the predictive power of zebra mussel filtration rate (ZMFR) by computing the summed Akaike weight of models that included ZMFR. To quantify the effect of the environmental factors on feeding success, we 
predicted dry mass at mean length for low (5th percentile) and high (95th percentile) values of the predictors in the best model. We performed mixed linear modeling using SAS for Windows 9.4 (PROC MIXED).

For analysis of diet composition, prey items from each stomach were identified to the lowest taxonomic level possible. We aggregated some prey taxa into higher levels in order to increase the frequency of occurrence. Prey weight was determined directly or was estimated using regressions of mass versus number. The proportional frequency of occurrence and the abundance of prey in the diet in terms of numbers and weight were calculated with the following equations (Brown et al. 2012):

Proportional frequency of occurrence (pFO):

$p F O_{i}=\frac{n_{i}}{n}$,

in which $n_{i}$ is the number of specimens with guts containing prey $\mathrm{i}$, and $\mathrm{n}$ is the total number of specimens;

Proportional abundance in terms of number and weight $\left(\mathrm{pN}_{\mathrm{i}}, \mathrm{pW}_{\mathrm{i}}\right)$ :

$p N_{i}=\sum_{j=1}^{n} p N_{i j} / n, \quad p W_{i}=\sum_{j=1}^{n} p W_{i j} / n$,

in which $\mathrm{pN}_{\mathrm{ij}}$ is the proportional numerical abundance of prey category $i$ in stomach sample $\mathrm{j}$ and $\mathrm{pW}_{\mathrm{ij}}$, is the proportional abundance in weight of prey category $\mathrm{i}$ in stomach sample $\mathrm{j}$;

Proportional prey-specific abundance in terms of number and weight $\left(\mathrm{pPN}_{\mathrm{i}}, \mathrm{pPW}_{\mathrm{i}}\right)$ :

$p P N_{i}=\sum_{j=1}^{n} p N_{i j} / n_{i}, p P W_{i}=\sum_{j=1}^{n} p W_{i j} / n_{i}$.

The prey-specific index of relative importance (\%PSIRI) was calculated as (Brown et al. 2012):

${ }_{0} \mathrm{PSIRI}_{i}=\frac{p F O_{i} *\left(p P N_{i}+p P W_{i}\right) * 100}{2}$.

All values were calculated by aggregating all individuals by location.

To assess differences in diet composition among years and periods, we performed a multivariate twoway analysis of similarity (ANOSIM). Analysis was conducted on a Bray-Curtis dissimilarity matrix that was constructed from the average $\log _{10}$ transformed numerical percentages of prey types (adding 1 to all values before log transformation). A Similarity Percentage Analysis (SIMPER) was performed to identify those prey items accounting for the most dissimilarity between years. For visual representation of mean dietary differences between years, we used non-metric multidimensional scaling ordination (NMDS) of the dissimilarity matrix produced by the ANOSIM analysis. Kruskal's stress statistic 1 was used to determine the best spatial representation of the different years; a stress of $<0.2$ was considered an acceptable fit (Clarke 1993). We predicted that a multivariate grouping of diet composition would be evident, such that diet during the mussel impact period would be distinct from the period before the invasion and that during the invasion recovery. All dietary comparisons were made with PRIMER Version 6 software (Primer-E Ltd., Plymouth UK).

\section{Results}

Two measures of feeding success varied concordantly among individuals. The short-term measure of individual feeding success (volume of gut contents) and the longer-term measure (condition as dry mass-at-length) were significantly but weakly correlated with each other after size adjustment $(R=0.11, N=642, p=0.005)$.

The volume of gut contents varied among years in both locations. Upriver and downriver values for annual mean volume of gut contents varied concordantly among years $(R=0.73, N=14, p=0.003)$. There was no overall difference with location (t-test $P=0.8$; Fig. 1a). Volume of gut contents varied among years upriver (ANCOVA: $\mathrm{F}_{11,293}=4.0, p<0.0001$; mixed linear model: $\left.\mathrm{F}_{11,254}=1.8, p=0.05\right)$ and downriver (ANCOVA: years $\mathrm{F}_{11,321}=7.6, p<0.0001$; mixed linear model $\mathrm{F}_{11,255}=3.3, p=0.0003$ ) but did not change with zebra mussel period in either river location.

Condition also varied among years in both locations. Upriver and downriver values for annual mean condition were not correlated with each other. There was no overall difference with location (t-test $P=0.28$; Fig. 1b). Condition varied among years upriver (ANCOVA: $\mathrm{F}_{11,374}=5.0, p<0.0001$; mixed linear model: $\mathrm{F}_{11,332}=2.4, p=0.004$ ) and downriver (ANCOVA: $\mathrm{F}_{11,425}=3.91 ; p<0.0001$; mixed linear model: $\left.\mathrm{F}_{11,354}=2.7, p=0.003\right)$. Condition did not change with zebra mussel invasion period in either river location.

Regressions taking multiple environmental variables into account indicate that zebra mussel filtration was associated with decreased condition in upriver locations (Table 3). No single set of upriver environmental 

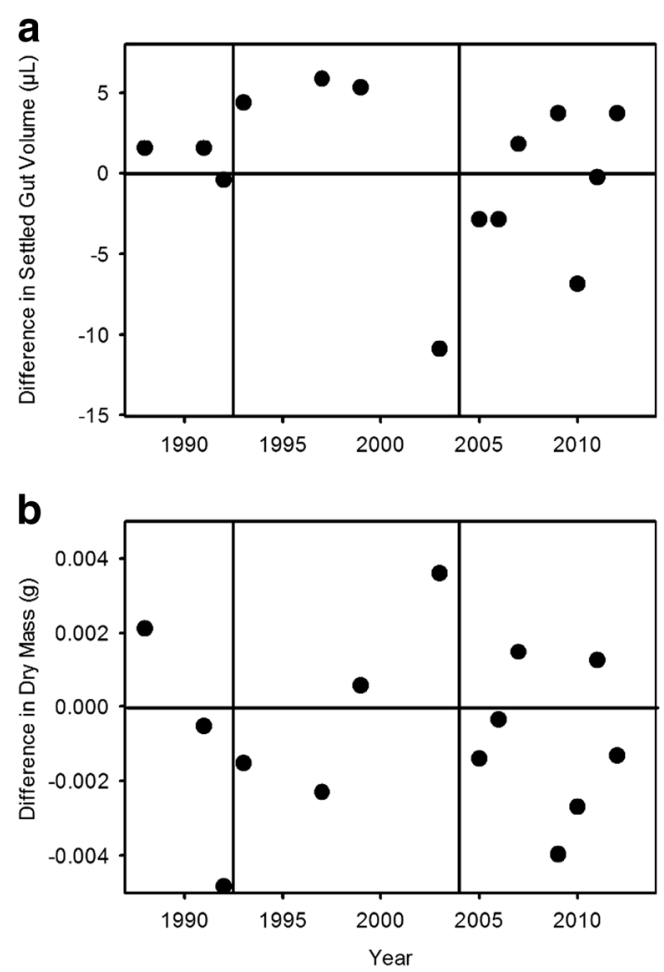

Fig. 1 Difference in (a) volume of gut contents and (b) condition between up- and downriver samples. Each point represents 60 fish. Values greater than zero (indicated by horizontal reference line) indicate that feeding success was higher in upriver locations than downriver locations. The figure is split into thirds by vertical lines to mark the zebra mussel invasion periods: pre-invasion, invasion impact, and recovery

variables yielded a best-fit model; ten models were nearly as good (i.e. $\triangle \mathrm{AIC}<2.0$ ) as the model with the lowest AIC value. Zebra mussel filtration rate (ZMFR) was a strong predictor. All of the best five models included ZMFR. The sum of Akaike weights over models including ZMFR was 0.99 (hence, the summed weights over models that omitted ZMFR was 0.01). Predictors in the model with the lowest AIC included salinity as well as ZMFR (Table 3a). Condition increased with salinity and decreased with ZMFR in all five best models (Table 3b). To assess the magnitude of environmental variability on condition, we estimated dry weight at mean length under low-condition (salinity at its 5th percentile, ZMFR at its 95th percentile) and high-condition (salinity at its 95 th percentile, ZMFR at its 5 th percentile) values for predictors. Condition was $33 \%$ higher when environmental predictors were favorable (i.e. dry mass $=0.017 \mathrm{~g}$ and $0.012 \mathrm{~g}$ respectively).

In downriver locations, three models that included copepods, dissolved oxygen and dissolved oxygen ${ }^{2}$ yielded the best fit (Table 3a). Three of the five best models also included ZMFR. ZMFR was a weak predictor relative to copepods and dissolved oxygen (summed Akaike weights of models with ZMFR $=0.67$; with copepods $=0.95$; with dissolved oxygen and/or dissolved oxygen $^{2}=0.92$ ). Condition increased with higher values of copepods and with higher values of ZMFR (Table 3b). The slopes for dissolved oxygen and dissolved oxygen ${ }^{2}$ were negative and positive respectively, indicating that there was a decelerating negative effect of dissolved oxygen on condition. Condition was $35 \%$ higher when environmental predictors were favorable (i.e. dry mass $=0.029 \mathrm{~g}$ and $0.039 \mathrm{~g}$ respectively).

Copepods and amphipods were predominant prey in the diet of Striped Bass in both river locations over the 14 years sampled (Table 4). In the upriver location, amphipods and copepods (prey-specific index of relative importance $=40 \%$ and $39 \%$ respectively) represented the dominant prey items. In the downriver location, amphipods (41\%), copepods (37\%), and mysids (19\%) constituted the majority of the diet (Table 4, Fig. 2). The $\mathrm{pN}$ of mysids in the downriver location was over five times that of mysids in the upriver location, whereas the $\mathrm{pN}$ of Leptodora in the upriver location was over ten times that of Leptodora in the downriver location. Diet composition did not differ among zebra mussel periods in both river locations; however, diet composition differed among years upriver (ANOSIM, global $R=0.27$, $p=0.001$ ) and downriver (ANOSIM, global $R=0.13$, $p=0.001)$. No temporal pattern in diet composition is evident in the upriver location (Fig. 3a), but 2009 diverged from other years, reflecting high consumption of Leptodora in that year. In the downriver location, the first four years lie on one edge of the multidimensional space opposite from one of the invasion-recovery years, 2010 (Fig. 3b). These differences are mostly explained by low consumption of mysids in the early years and high consumption of mysids in 2010. Diet of larval and juvenile Striped Bass was similar; copepods and amphipods dominated the diet of both life stages and their representation in the diet was similar in upriver and downriver locations (Table 5).

\section{Discussion}

To our knowledge, this study is the first to examine the feeding ecology of early-stage fishes over a multidecade time span. We found that zebra mussel filtration 
Table 3 Selected regression models to predict condition in upriver and down river samples. Response variable in each regression is $\log$ (dry weight). Predictors include chlorophyll $a$ (Chl, $\mu \mathrm{g}^{-1}$ ), copepod density $\left(\mathrm{Cop}, \mathrm{l}^{-1}\right)$, dissolved oxygen (DO $\mathrm{mg} \mathrm{l}^{-1}$ ), salinity (sal, ppt), temperature (Temp, $\left.{ }^{\circ} \mathrm{C}\right)$. a) Statistics used in model evaluation. For each model 1-5, listed in order of model quality, table lists predictors in the model (with the exception of $\log$ (length), which is in every model), Akaike's Information Criterion (AIC), difference in AIC between models 2-4 and model 1 ( $\triangle \mathrm{AIC})$, Akaike weight (Wt). b) Summary of variable estimates. For each model 1-5, table lists slopes of predictors in the model, with the exception of predictors $\log$ (length) (upriver range: 3.32 3.35; downriver range: $3.34-3.36$ ) and the intercept (upriver range: $-6.19--6.17$; downriver range: $-6.16--6.14$ )

\begin{tabular}{|c|c|c|c|c|c|c|c|c|c|c|c|}
\hline \multicolumn{12}{|l|}{ a) } \\
\hline Model & Predictors & AIC & $\triangle \mathrm{AIC}$ & & Wt & Model & Predictors & AIC & & $\triangle \mathrm{AIC}$ & Wt \\
\hline 1 & Sal, ZMFR & -720.4 & 0 & & 0.0440 & 1 & Cop, DO, $\mathrm{DO}^{2}, \mathrm{ZMFR}$ & -1059 & & 0 & 0.288 \\
\hline 2 & DO, Sal, ZMFR & -720.3 & 0.100 & & 0.0419 & 2 & Chl, Cop, DO, DO ${ }^{2}$, ZMFR & -1057 & & 1.80 & 0.117 \\
\hline 3 & Cop, DO, Sal, ZMFR & -719.3 & 1.100 & & 0.0254 & 3 & Cop, DO, $\mathrm{DO}^{2}$ & -1057 & & 1.80 & 0.117 \\
\hline 4 & Sal, Temp ${ }^{2}$, ZMFR & -718.9 & 1.500 & & 0.0208 & 4 & Cop, DO, ZMFR & -1056 & & 2.80 & 0.0710 \\
\hline 5 & Cop, Sal, ZMFR & -718.9 & 1.500 & & 0.0208 & 5 & Chl, Cop, DO, DO ${ }^{2}$ & -1054.8 & & 3.80 & 0.0431 \\
\hline \multicolumn{12}{|l|}{ b) } \\
\hline Model & $\mathrm{Chl}$ & Cop & Sal & Temp $^{2}$ & ZMFR & Model & Chl & Cop & DO & $\mathrm{DO}^{2}$ & ZMFR \\
\hline 1 & & & 0.0822 & & -0.0101 & 1 & & 0.00388 & -0.0345 & 0.0138 & 0.00352 \\
\hline 2 & & 0.0134 & 0.100 & & -0.0111 & 2 & 0.000376 & 0.00404 & -0.0346 & 0.0144 & 0.00376 \\
\hline 3 & 0.00196 & 0.0148 & 0.106 & & -0.0109 & 3 & & 0.00324 & -0.0334 & 0.0130 & \\
\hline 4 & & & 0.0776 & 0.000543 & -0.0100 & 4 & & 0.00366 & -0.0263 & & 0.00334 \\
\hline 5 & 0.00141 & & 0.0848 & & -0.00992 & 5 & -0.000090 & 0.00322 & -0.0334 & 0.0129 & \\
\hline
\end{tabular}

Table 4 Prey of striped bass from upriver and downriver locations in the Hudson River estuary, quantified by mean proportional numerical abundance $(\mathrm{pN})$, mean proportional prey-specific numerical abundance (pPN), mean proportional abundance in weight
$(\mathrm{pW})$, mean proportional prey specific abundance in weight (pPW), mean proportional frequency of occurrence $(\mathrm{pFO})$, and percent prey specific index of relative importance (\%PSIRI)

\begin{tabular}{|c|c|c|c|c|c|c|c|c|c|c|c|c|}
\hline \multirow[t]{2}{*}{ Prey Taxon } & \multicolumn{6}{|l|}{ Upriver } & \multicolumn{6}{|c|}{ Downriver } \\
\hline & $\mathrm{pN}$ & $\mathrm{pPN}$ & pW & pPW & $\mathrm{pFO}$ & $\%$ PSIRI & $\mathrm{pN}$ & $\mathrm{pPN}$ & pW & pPW & $\mathrm{pFO}$ & $\%$ PSIRI \\
\hline Copepoda & 0.45 & 0.73 & 0.36 & 0.58 & 0.62 & 40.2 & 0.41 & 0.79 & 0.33 & 0.64 & 0.52 & 37.1 \\
\hline \multicolumn{13}{|l|}{ Amphipoda: } \\
\hline Gammaridae & 0.20 & 0.53 & 0.26 & 0.68 & 0.38 & 22.9 & 0.17 & 0.56 & 0.19 & 0.61 & 0.30 & 17.8 \\
\hline Corophiidae & 0.0100 & 0.78 & 0.0089 & 0.69 & 0.013 & 0.94 & 0.013 & 0.34 & 0.018 & 0.46 & 0.039 & 1.55 \\
\hline Unidentified & 0.15 & 0.55 & 0.18 & 0.67 & 0.27 & 16.4 & 0.18 & 0.60 & 0.20 & 0.65 & 0.31 & 19.2 \\
\hline Mysida & 0.022 & 0.74 & 0.028 & 0.95 & 0.030 & 2.52 & 0.16 & 0.71 & 0.21 & 0.93 & 0.22 & 18.3 \\
\hline Leptodora & 0.085 & 0.79 & 0.088 & 0.82 & 0.11 & 8.61 & 0.0070 & 0.54 & 0.0049 & 0.38 & 0.013 & 0.59 \\
\hline Bosmina & 0.025 & 0.39 & 0.030 & 0.47 & 0.064 & 2.77 & 0.0042 & 0.14 & 0.0058 & 0.19 & 0.030 & 0.50 \\
\hline Sididae & 0.012 & 0.47 & 0.016 & 0.61 & 0.026 & 1.39 & 0.017 & 0.50 & 0.019 & 0.55 & 0.034 & 1.80 \\
\hline Podocopa & 0.019 & 0.21 & 0.0037 & 0.042 & 0.090 & 1.13 & 0.0030 & 0.17 & 0.0004 & 0.023 & 0.017 & 0.17 \\
\hline Chydoridae & 0.0045 & 0.35 & 0.0043 & 0.33 & 0.013 & 0.44 & 0.0079 & 0.46 & 0.0018 & 0.10 & 0.017 & 0.48 \\
\hline Daphnia & 0.0011 & 0.25 & 0.0001 & 0.031 & 0.0043 & 0.0600 & 0.0033 & 0.38 & 0.0004 & 0.042 & 0.0086 & 0.18 \\
\hline Cumacea & 0.0053 & 0.31 & 0.0046 & 0.27 & 0.017 & 0.50 & 0.0027 & 0.21 & 0.0004 & 0.028 & 0.013 & 0.15 \\
\hline Bivalvia & 0.0056 & 0.33 & 0.0043 & 0.25 & 0.017 & 0.49 & 0.0029 & 0.67 & 0.0023 & 0.54 & 0.0043 & 0.26 \\
\hline Chironomidae & 0.0056 & 0.44 & 0.0072 & 0.56 & 0.013 & 0.64 & 0.0099 & 0.23 & 0.016 & 0.38 & 0.043 & 1.31 \\
\hline Clupeidae & 0.0078 & 0.61 & 0.012 & 0.94 & 0.013 & 0.99 & 0.0038 & 0.44 & 0.0079 & 0.92 & 0.0086 & 0.58 \\
\hline
\end{tabular}



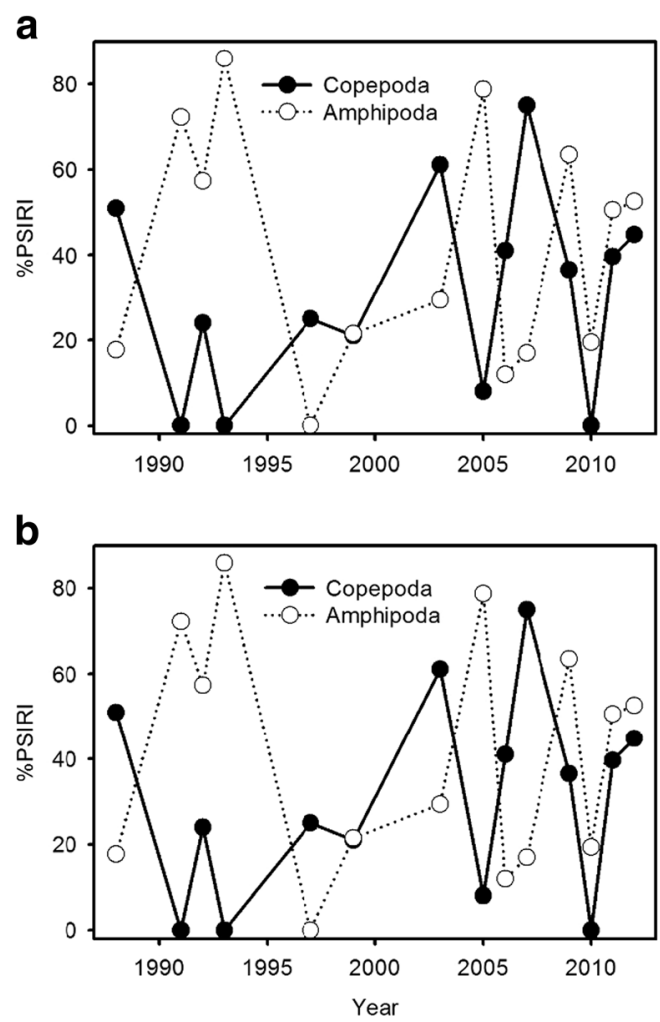

Fig. 2 Annual mean \%PSIRI of copepods and amphipods (all families combined) for (a) upriver and (b) downriver samples

was associated with reduced feeding success of earlystage Striped Bass in upriver locations of the Hudson River Estuary where the mussels now live. The invasion of zebra mussels did not have a clear effect on diet composition.

The diet was composed predominantly of copepods and amphipods, and was similar between locations. Previous studies (Hurst and Conover 2001; Jordan et al. 2003; Limburg et al. 1997) also found that earlystage bass fed primarily on copepods and amphipods as well as Bosmina, which was not well represented in the diets of our samples. The scarcity of Bosmina within our samples is likely a result of high seasonal variation in abundance: Bosmina displays a pattern of dramatic increase and decline in May through June (Limburg et al. 1997; Strayer et al. 1999). Most of our samples were taken after the major Bosmina bloom would be expected. In terms of overall \%PSIRI, copepods were the most important prey item upriver and second-most important downriver. The importance of copepods in the diet of young-of-the-year Striped Bass has been highlighted in other studies (Gardinier and Hoff 1982; Limburg et al. 1997; Markle and Grant 1970) and may be explained by
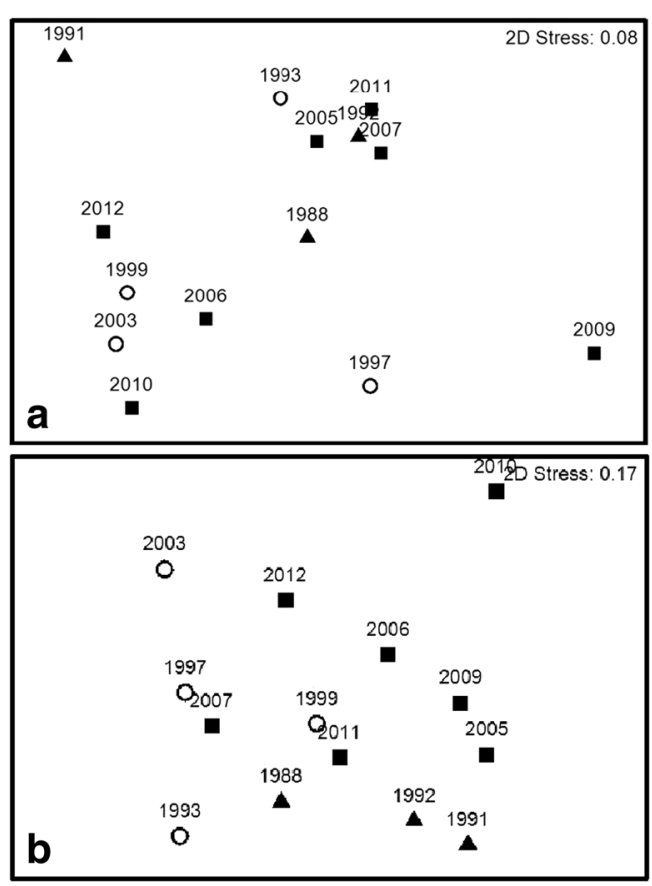

Fig. 3 Non-metric multidimensional scaling plot of (a) upriver and (b) downriver diet composition. Distance between points indicates dissimilarity. Solid triangles represent years of the preinvasion period, open circles represent years of the invasionimpact period, and solid squares represent years of the recovery period

their relatively stable abundance. Even in years of zebra mussel impacts, when some types of zooplankton were greatly depleted, copepod abundances remained stable (Pace et al. 1998). The prevalence of amphipods in the diet across years, particularly downriver, was similarly observed by Jordan et al. (2003) and Gardinier and Hoff (1982). Prey that shifted in importance along-river included Leptodora, which is a freshwater cladoceran (Browman et al. 1989), and mysids, most of which are found in marine and brackish waters (Smith 2001).

We analyzed two indices of feeding success in this study. Volume of gut contents provides a short-term (i.e. hours) record of recent feeding given short passage time (Govoni et al. 1986), whereas morphometric indices of condition can accurately assess feeding success over a period of several days (Ferron and Leggett 1994). The short-term measure should be more subject to stochastic variability and high-frequency influences such as diel timing of sampling. As expected, volume of gut contents was less well predicted by explanatory variables than dry mass (e.g., in regression against length, $\mathrm{R}^{2}=0.24$ and 0.98 respectively). Nonetheless, the two measures of feeding success were intercorrelated, 
Table 5 Predominant prey of larval (a) and juvenile (b) striped bass from upriver and downriver locations in the Hudson River estuary, quantified by mean proportional numerical abundance $(\mathrm{pN})$, mean proportional prey-specific numerical abundance $(\mathrm{pPN})$, mean proportional abundance in weight $(\mathrm{pW})$, mean proportional prey specific abundance in weight ( $\mathrm{pPW}$ ), mean proportional frequency of occurrence ( $\mathrm{pFO}$ ), and percent prey specific index of relative importance (\%PSIRI). Table presents only values for copepod and amphipod prey types to facilitate comparisons between life stages. Each value represents a 14-year average

\begin{tabular}{|c|c|c|c|c|c|c|c|c|c|c|c|c|}
\hline \multirow[b]{2}{*}{$\begin{array}{l}\text { Prey Taxon } \\
\text { a) }\end{array}$} & \multicolumn{6}{|c|}{ Upriver } & \multicolumn{6}{|c|}{ Downriver } \\
\hline & $\mathrm{pN}$ & $\mathrm{pPN}$ & $\mathrm{pW}$ & pPW & $\mathrm{pFO}$ & $\%$ PSIRI & $\mathrm{pN}$ & $\mathrm{pPN}$ & $\mathrm{pW}$ & $\mathrm{pPW}$ & $\mathrm{pFO}$ & \%PSIRI \\
\hline Copepoda & 0.46 & 0.73 & 0.36 & 0.57 & 0.63 & 40.6 & 0.47 & 0.88 & 0.39 & 0.73 & 0.54 & 43.1 \\
\hline \multicolumn{13}{|l|}{ Amphipoda: } \\
\hline Gammaridae & 0.18 & 0.50 & 0.24 & 0.67 & 0.36 & 20.8 & 0.20 & 0.65 & 0.21 & 0.69 & 0.31 & 20.7 \\
\hline Unidentified & 0.16 & 0.57 & 0.19 & 0.69 & 0.28 & 17.3 & 0.15 & 0.62 & 0.16 & 0.68 & 0.24 & 15.4 \\
\hline \multicolumn{13}{|l|}{ b) } \\
\hline Copepoda & 0.38 & 0.75 & 0.35 & 0.69 & 0.50 & 36.2 & 0.33 & 0.66 & 0.23 & 0.47 & 0.49 & 28.0 \\
\hline \multicolumn{13}{|l|}{ Amphipoda: } \\
\hline Gammaridae & 0.40 & 0.68 & 0.42 & 0.72 & 0.58 & 40.9 & 0.13 & 0.42 & 0.15 & 0.48 & 0.30 & 13.6 \\
\hline Unidentified & 0.08 & 0.40 & 0.09 & 0.43 & 0.21 & 8.66 & 0.24 & 0.58 & 0.26 & 0.62 & 0.42 & 25.1 \\
\hline
\end{tabular}

indicating that some of the processes affecting variability in volume of gut contents were sufficiently sustained to affect condition as well. We found a strong effect of year on both indices of feeding success. We expected to find that measures of long-term feeding success were higher downriver. In juvenile euryhaline species, higher salinities are typically associated with higher specific growth rate, efficient food conversion ratio, and energy absorption efficiency (Altinokand and Grizzle 2001). This prediction was not supported by our data.

We found that associations of environmental variables with long-term feeding success differed with location. In upriver locations, high values of salinity and low values of zebra mussel grazing rate were associated with higher condition in the best explanatory models, and some of these models indicated associations with higher values of copepod abundance, higher values of dissolved oxygen, and a quadratic effect of temperature. The association between condition and an estimate of annual mean zebra mussel filtration rate supports the inference of previous studies (Strayer et al. 2004, 2014b) that depletion of production in the water column by zebra mussels has reduced feeding opportunities for young fish. Salinity at the time and location that the fish were sampled modulated the association with zebra mussel grazing, perhaps indicating a transient inhibition of grazing or an intrusion of forage for early-stage fishes from downriver locations. In downriver locations, high values of copepod abundance and low values of dissolved oxygen were associated with higher condition in the best explanatory models, and some of these models indicated associations with higher values of zebra mussel grazing and higher or lower values of chlorophyll. This positive effect of annual mean copepod abundance on condition indicates that the availability of a predominant prey item drives feeding opportunities. The negative effect of dissolved oxygen is surprising, given that decreasing dissolved oxygen generally results in decreased growth and food intake in fish (Brett and Groves 1979; Jobling 1993), and that low dissolved oxygen levels influence pathways of energy flow in estuaries (Breitburg et al. 1997; Wu 2002). On the other hand, the samples we analyzed were not subject to hypoxic conditions (i.e. the 5 th percentile of $\mathrm{dO}_{2}$ was $5.6 \mathrm{mg}^{-1}$, well above a generally accepted value for hypoxia of $2 \mathrm{mg}^{-1}$ ). It is likely that dissolved oxygen at these levels doesn't directly affect condition, but instead it reflects the influence of some other factor that we have not accounted for in our modeling, or is aliased with combinations of other measured variables such as temperature and salinity.

We emphasized information theoretic criteria for model selection in our analyses. We favored this 
approach over selection of variables according to $p$ values, because we sought the set of variables that best fit the data, rather than selecting variables that were least likely to have had no effect. Lively discussion continues on the relative merits of information-theoretic criteria versus significance testing (Murtaugh 2014), but there is general agreement that either should be supplemented by estimates of effect size. We have done so by showing that an individual in a favorable environment, according to the selected model, would be $33 \%$ - $35 \%$ heavier at length than an individual in a poor environment. We regard these as relatively dramatic differences in condition. We note also that $p$-values of all predictor variables in the best-selected models were $\leq 0.05$.

This study is the first to investigate zebra mussel effects on early-stage Striped Bass feeding ecology. Given the mussel's dramatic impacts on the estuary's trophic structure (Strayer et al. 1999, 2014a), it was plausible to expect that feeding success had declined during years of high impact, particularly upriver where zebra mussels are abundant. Prior work suggesting this had motivated the present study: Strayer et al. (2004) found that apparent growth rates of juvenile Striped Bass was lower in the freshwater portion of the estuary during what we refer to here as the invasion impact period, relative to the pre-invasion period. Subsequently, during what is termed the recovery period, Striped Bass growth rate did not rebound, unlike that of other open-water feeding species such as American Shad (Strayer et al. 2014b). We find that feeding success did not vary according to the pre-invasion, invasion impact and recovery periods, despite pronounced interannual variability. The association with zebra mussel was revealed in regressions that modelled zebra mussel effects as a continuous variable in conjunction with other predictors, thus quantitatively representing annual differences in zebra mussel grazing as well as variability in other environmental factors that could directly or indirectly influence feeding success.

Zebra mussel have affected diet composition and feeding success of fishes in other systems. In the Great Lakes, the appearance of zebra mussel depleted populations of the amphipod Diporeia, which forced Lake Whitefish and Alewives to shift their prey use; feeding success declined, as did growth rate and condition (Madenjian et al. 2015; Pothoven et al. 2001; Pothoven and Madenjian 2008). Some fishes incorporate zebra mussels into their diets (French and Bur 1996; Nack et al. 2015; Pothoven et al. 2001; Ruetz et al. 2012; Watzin et al. 2008), but we found no evidence of early stage Striped Bass feeding on zebra mussel veligers. Other molluscs occurred as rare prey in Striped Bass and other early-stage fishes in our samples; thus we regard as possible but unlikely that the absence of young bivalves in our samples might be attributable to preservation in formalin.

About $25 \%$ of early stage striped bass guts were empty in our samples. Specimens collected for this study were all taken at night so that survey catchability would be high, whereas most dietary studies that report sampling time occurred during daylight hours. Although Striped Bass larvae do feed at night (Chesney 1989; McHugh and Heidinger 1977), Duston and Astatkie (2012) found that the prey capture rate of larval Striped Bass at night depends on prey densities; visual feeding was up to four-fold more effective than nonvisual feeding at low prey densities but similar at the highest densities. Nonetheless, we found no effect of tow time on gut fullness (results not shown). We acknowledge that this does not ensure that nighttime tows provide a complete picture of feeding ecology. Future studies in the Hudson might incorporate daytime samples to compliment the data we have shown.

This research underscores the value of studying longterm ecological data by enabling us to assess how Striped Bass feeding ecology has responded to complex phenomena that occurred over a prolonged period within an estuary. If we had taken a cross-sectional approach, we might have drawn different conclusions based on isolated events or fluctuations in environmental factors that wouldn't have been accounted for in our data set. This study also sheds light on the importance of longterm environmental sampling programs and associated samples. Archived samples enabled us to characterize 14 years of Striped Bass diet composition and to demonstrate the effect on trophic ecology of early stage Striped Bass of zebra mussels within the Hudson River estuary. The value of long-term monitoring studies is closely tied to decisions about what and how to monitor (Lindenmayer and Likens 2009); we also recommend careful consideration of what samples to preserve and how to preserve them. It is unfortunate that our formalin-fixed and preserved samples could not furnish direct estimates of growth rate via otolith daily increment analysis. Future studies that examine the trophic impact of further zebra mussel expansion and that of other invasive species on early-stage fishes should combine analysis of feeding ecology as well as measures of individual vital rates such as growth. 
Acknowledgements We thank Normandeau Associates and the New York State Museum for providing the samples for this study. Alan Bullock, Hannah Proctor, and Bryan Weatherwax coordinated specimen transfers. John Young of ASA Analysis and Communications assisted with water quality datasets. John Young and Sebastian A. Klarian helpfully commented on manuscript drafts. The following University of Connecticut students helped with specimen processing and data collection: Allison Villa, Harley Pastore, Keith Berggren, Mary Ward, Kayla Delventhal, Jacob Hudobenko, Lucie Rodriguez, Mark Schuman, Allison Ballek, Hayley Morway, Sophie Van Etten, Allison Brodeur, Miranda Lin, Chloe Toso, and Brian Ruger. Funding for this work was provided by the Hudson River Foundation (Grant \#008/13A). Some of the data used herein were collected with the support of the LTREB program (DEB-1119739) of the National Science Foundation.

Open Access This article is distributed under the terms of the Creative Commons Attribution 4.0 International License (http:// creativecommons.org/licenses/by/4.0/), which permits unrestricted use, distribution, and reproduction in any medium, provided you give appropriate credit to the original author(s) and the source, provide a link to the Creative Commons license, and indicate if changes were made.

\section{References}

Akaike H (1974) A new look at the statistical model identification. IEEE T Automat Contr 19:716-723

Alcaraz C, Gholami Z, Esmaeili HR, García-Berthou E (2015) Herbivory and seasonal changes in diet of a highly endemic cyprinodontid fish (Aphanius farsicus). Environ Biol Fish 98:1541-1554

Altinokand I, Grizzle JM (2001) Effects of brackish water on growth, feed conversion and energy absorption efficiency by juvenile euryhaline and freshwater stenohaline fishes. J Fish Biol 59:1142-1152

ASA Analysis and Communication (2016) 2014 year class report for the Hudson River estuary monitoring program. Washingtonville, NY

Baxter CV, Fausch KD, Saunders WC (2005) Tangled webs: reciprocal flows of invertebrate prey link streams and riparian zones. Freshw Biol 50:201-220

Blaber SJM, Blaber TG (1980) Factors affecting the distribution of juvenile estuarine and inshore fish. J Fish Biol 17:143-162

Braga RR, Bornatowski H, Vitule JRS (2012) Feeding ecology of fishes: an overview of worldwide publications. Rev Fish Biol Fisher 22:915-929

Breitburg DL, Loher T, Pacey CA, Gerstein A (1997) Varying effects of low dissolved oxygen on trophic interactions in an estuarine food web. Ecol Monogr 67:489-507

Brett J, Groves T (1979) Physiological energetics. Fish Physiology $8: 279-352$

Browman HI, Kruse S, O'Brien WJ (1989) Foraging behavior of the predaceous cladoceran, Leptodora kindti, and escape responses of their prey. J Plankton Res 11:1075-1088

Brown SC, Bizzarro JJ, Cailliet GM, Ebert DA (2012) Breaking with tradition: redefining measures for diet description with a case study of the Aleutian skate Bathyraja aleutica (Gilbert 1896). Environ Biol Fish 95(1):3-20

Burnham KP, Anderson D (2002) Model selection and multimodel inference: a practical information-theoric approach, 2nd edn. Springer, New York

Caraco NF, Cole JJ, Raymond PA, Strayer DL, Pace ML, Findlay SE, Fischer DT (1997) Zebra mussel invasion in a large, turbid river: phytoplankton response to increased grazing. Ecology 78:588-602

Chesney EJ Jr (1989) Estimating the food requirements of striped bass larvae Morone saxatilis: effects of light, turbidity and turbulence. Mar Ecol-Prog Ser 53:191-200

Clarke KR (1993) Non-parametric multivariate analyses of changes in community structure. Aust J Ecol 18:117-143

Collar DC, O'Meara BC, Wainwright PC, Near TJ (2009) Piscivory limits diversification of feeding morphology in centrarchid fishes. Evolution 63:1557-1573

Donadelli V, Longobardi A, Finoia MG, Marino G (2015) Feeding hatchery-reared dusky grouper Epinephelus marginatus juveniles on live prey: implications for restocking. Environ Biol Fish 98:1757-1766

Duston J, Astatkie T (2012) Prey density and nonvisual feeding by larval striped bass. T Am Fish Soc 141:610-614

Feitosa JLL, Ferreira BP (2015) Distribution and feeding patterns of juvenile parrotfish on algal-dominated coral reefs. Mar Ecol 36:462-474

Ferron A, Leggett WC (1994) An appraisal of condition measures for marine fish larvae. Adv in Mar Biol 30:217-303

French JRP, Bur MT (1996) The effect of zebra mussel consumption on growth of freshwater drum in Lake Erie. J Freshw Ecol 11:283-289

Friedland KD, Ahrenholz DW, Guthrie JF (1996) Formation and seasonal evolution of Atlantic menhaden juvenile nurseries in coastal estuaries. Estuaries 19:105-114

Gardinier MN, Hoff TB (1982) Diet of striped bass in the Hudson River estuary (Morone saxatilis). New York Fish Game J 29: $152-165$

Gerking SD (1994) Feeding ecology of fish. Academic Press, San Diego, California

Govoni JJ, Boehlert GW, Watanabe Y (1986) The physiology of digestion in fish larvae. Environ Biol Fish 16:59-77

Hardy JD (1978) Development of fishes of the Mid-Atlantic Bight - an atlas of egg, larval, and juvenile stages. - Volume IIIAphredoderidae through Rachycentridae. Department of the Interior Fish and Wildlife Service, Washington DC

Howe DV, Jordan RC, Juanes F (2008) Selective feeding in a generalist invertivore, age-0 striped bass. Ecol Freshwater Fish 17:495-501

Hurst TP, Conover DO (2001) Diet and consumption rates of overwintering YOY striped bass, Morone saxatilis, in the Hudson River. Fishery B-NOAA 99:545-553

Hyslop EJ (1980) Stomach content analysis- a review of methods and their applications. J Fish Biol 17:411-429

Jakob EM, Marshall SD, Uetz GW (1996) Estimating fitness: a comparison of body condition indices. Oikos 77(1):61-67

Jobling M (1993) Bioenergetics: feed intake and energy partitioning. In: Rankin JC, Jensen FB (eds) Fish ecophysiology. Chapman and Hall, London, pp. 1-44

Johnston TA, Mathias JA (1993) Length reduction and dry weight loss in frozen and formalin-preserved larval walleye, Stizostedion vitreum (Mitchill). Aquac Res 24:365-371 
Jordan RC, Howe DV, Hurst TP, Juanes F (2003) Feeding habits of age-0 striped bass, Morone saxatilis, in the mid-Hudson River estuary: temporal, spatial, and ontogenetic variation. Estuaries 26:1486-1493

Jude DJ (1973) Food and feeding habits of gizzard Shad in pool 19 Mississippi River. T Am Fish Soc 102:378-383

Levinton JS, Waldman JR (eds) (2006) The Hudson River estuary. Cambridge University Press, New York

Limburg KE, Pace ML, Fischer D, Arend KK (1997) Consumption, selectivity, and use of zooplankton by larval striped bass and white perch in a seasonally pulsed estuary. $\mathrm{T}$ Am Fish Soc 126:607-621

Lindenmayer DB, Likens GE (2009) Adaptive monitoring: a new paradigm for long-term research and monitoring. Trends Ecology Evolution 24:482-486

Lindenmayer DB, Likens GE, Andersen A, Bowman D, Bull CM, Burns E, Dickman CR, Hoffmann AA, Keith DA, Liddell MJ, Lowe AJ, Metcalfe DJ, Phinn SR, Russell-Smith J, Thurgate N, Wardle GM (2012) Value of long-term ecological studies. Austral Ecol 37:745-757

Llopiz JK (2013) Latitudinal and taxonomic patterns in the feeding ecologies of fish larvae: a literature synthesis. J Marine Syst 109-110:69-77

MacLusky DS, Elliott M (2004) The estuarine ecosystem: ecology, threats, and management, 3rd edn. Oxford University Press, New York

Madenjian CP et al (2015) Changes in the Lake Michigan food web following dreissenid mussel invasions: a synthesis. Journal of Great Lakes research 41. Supplement 3:217-231

Markle DF, Grant GC (1970) The summer food habits of youngof-the year striped bass in three Virginia Rivers. Chesap Sci 11:50-54

McHugh JJ, Heidinger RC (1977) Effects of light on feeding and egestion time of striped bass fry. Prog Fish Cult 39:33-34

Morgan RP, Rasin VJ, Copp RL (1981) Temperature and salinity effects on development of striped bass eggs and larvae. TAm Fish Soc 110:95-99

Murtaugh PA (2014) In defense of $P$ values. Ecology 95:611-617

Nack CC, Limburg KE, Schmidt RE (2015) Diet composition and feeding behavior of larval American Shad, Alosa sapidissima (Wilson), after the introduction of the invasive zebra mussel, Dreissena polymorpha (Pallas), in the Hudson River estuary, NY. Northeast Nat 22:437-450

O'Connor MP, Juanes F, McGarigal K, Caris J (2012) Describing juvenile American shad and striped bass habitat use in the Hudson River estuary using species distribution models. Ecol Eng 48:101-108

Pace ML, Findlay SEG, Fischer D (1998) Effects of an invasive bivalve on the zooplankton community of the Hudson River. Freshw Biol 39:103-116

Pace ML, Strayer DL, Fischer D, Malcom HM (2010) Recovery of native zooplankton associated with increased mortality of an invasive mussel. Ecosphere 1:1-10

Parker RR (1963) Effects of formalin on length and weight of fishes. Journal Fish Board Can 20:1441-1455

Pothoven SA, Madenjian CP (2008) Changes in consumption by alewives and lake whitefish after dreissenid mussel invasions in lakes Michigan and Huron. N Am J Fish Manage 28:308320

Pothoven SA, Nalepa TF, Schneeberger PJ, Brandt SB (2001) Changes in diet and body condition of lake whitefish in southern Lake Michigan associated with changes in benthos. N Am J Fish Manage 21:876-883

Ruetz CR, Reneski MR, Uzarski DG (2012) Round goby predation on Dreissena in coastal areas of eastern Lake Michigan. J Freshw Ecol 27:171-184

Schultz ET, Young J, Martin JM, Lwiza KM (2005) Tracking cohorts: analysis of migration in the early life stages of an estuarine fish. Estuaries 28:394-405

Shields PA, Carlson SR (1996) Effects of formalin and alcohol preservation on lengths and weights of juvenile sockeye Salmon. Alaska Fish Res Bull 3:81-93

Smith DG (2001) Minor Malacostraca. In: Pennak's freshwater invertebrates of the United States: Porifera to Crustacea, 4th edn. John Wiley and Sons, Canada, pp. 545-551

Strayer DL, Smith LC (2001) The zoobenthos of the freshwater tidal Hudson River and its response to the zebra mussel (Dreissena polymorpha) invasion. Arch Hydrobiol Suppl 139:1-52

Strayer DL, Powell J, Ambrose P, Smith LC, Pace ML, Fischer DT (1996) Arrival, spread, and early dynamics of a zebra mussel (Dreissena polymorpha) population in the Hudson River estuary. Can J Fish Aquat Sci 53:1143-1149

Strayer DL, Caraco NF, Cole JJ, Findlay S, Pace ML (1999) Transformation of freshwater ecosystems by bivalves: a case study of zebra mussels in the Hudson River. Bioscience 49: $19-27$

Strayer DL, Hattala KA, Kahnle AW (2004) Effects of an invasive bivalve (Dreissena polymorpha) on fish in the Hudson River estuary. Can J Fish Aquat Sci 61:924-941

Strayer DL, Cid N, Malcom HM (2011) Long-term changes in a population of an invasive bivalve and its effects. Oecologia 165:1063-1072

Strayer DL, Cole JJ, Findlay SE, Fischer DT, Gephart JA, Malcom HM, Pace ML, Rosi-Marshall EJ (2014a) Decadal-scale change in a large-river ecosystem. Bioscience 64:496-510

Strayer DL, Hattala KA, Kahnle AW, Adams RD (2014b) Has the Hudson River fish community recovered from the zebra mussel invasion along with its forage base? Can J Fish Aquat Sci 71:1146-1157

Waldman JR (2006) The diadromous fish fauna of the Hudson River: life histories, conservation concerns, and research avenues. In: Levinton JS, Waldman JR (eds) The Hudson River estuary. Cambridge University Press, New York, pp. 171-188

Watzin MC, Joppe-Mercure K, Rowder J, Lancaster B, Bronson L (2008) Significant fish predation on zebra mussels Dreissena polymorpha in Lake Champlain, U.S.a. J Fish Biol 73:15851599

Wu RS (2002) Hypoxia: from molecular responses to ecosystem responses. Mar Pollut Bull 45:35-45

Yeh CF, Hodson RG (1975) Effects of formalin on length and weight of bluegill and white crappie from Lake Nasworthy. Texas Southwest Nat:315-321 